\title{
Fungi Associated with the Deterioration of Post-harvest Onion Bulbs Sold in Some Markets in Awka, Nigeria
}

\author{
Onuorah Samuel $^{1, *}$, Obika Ifeanyi ${ }^{2}$ \\ ${ }^{1}$ Department of Applied Microbiology and Brewing, Nnamdi Azikiwe University, Nigeria \\ ${ }^{2}$ Department of Zoology, Nnamdi Azikiwe University, Nigeria
}

Copyright $(\subset 2015$ by authors, all rights reserved. Authors agree that this article remains permanently open access under the terms of the Creative Commons Attribution License 4.0 International License

\begin{abstract}
Onion bulbs rots are caused by microorganisms especially fungi leading to economic loss. These fungi have been known to produce toxins which are injurious to human and animal health, therefore in this study, the fungi associated with the spoilage of onions bulbs purchased from Umuike, Amaikwo, Amaudo, Okpuno and Permanent site markets were isolated, characterized and identified. The average fungal counts ranged between $1.2 \times 10^{3} \mathrm{CfU} / \mathrm{ml}$ and $2.0 \times 10^{3} \mathrm{CfU} / \mathrm{ml}$. The fungi isolated from the spoilt onion bulbs were Penicillum digitatum, Fusarium oxysporum, Rhizopus stolonifer, Alternaria alternata, Aspergillus niger and Saccharomyces cerevisiae. The samples from Amaudo market had the highest percentage distribution of fungi of $34.2 \%$ while those from permanent site had the least percentage distribution of $8.6 \%$. Aspergillus niger had the highest percentage distribution of $34.29 \%$ in the spoilt onion bulbs while Saccharomyces cerevisiae had the least percentage distribution of 5.71\%. Aspergillus niger also had the highest rot diameter of $40 \mathrm{~mm}$ while Saccharomyces cerevisiae had the least rot diameter of $16 \mathrm{~mm}$. Adequate mycological knowledge, storage facilities and handling practices would therefore minimize the deterioration of onion bulbs thereby ensuring its availability to the society all year round.
\end{abstract}

Keywords Fungi, Deterioration, Post-harvest, Onion Bulbs, Markets

\section{Introduction}

Onion (Allium cepa L.) is an important vegetable crop in Nigeria based on consumption and economic values to farmers. It is one of the most important and familiar spice crops throughout the world. The crop is grown for its bulbs which are harvested in most countries once a year and are used daily in every home for seasoning and flavouring of foods. Onion is a valuable ingredient in the diet due to its content of sugars, vitamins, minerals, electrolytes, proteins and dietary fibre [1-3].

Numerous benefits have been attributed to onions including prevention of cancer and cardiovascular disorders, reduction in the blood levels of cholesterol, reduction in osteoporosis, reduction in stomach ulcers, inhibition of the proliferation of cultured ovarian, breast and colon cancer cells, inhibition of platelets-mediated thrombosis, prevention of inflammatory processes associated with asthma, treatment of fever, common cold, cough, sore throat and its use as an antimicrobial agent $[4,5]$.

Onions are packed locally in baskets and jute bags. These packaging materials come from palm, bamboo and fibrous jute trees. However these materials provide no barriers of dust, and can easily be crushed which might lead to damage of the onions. During storage, some losses occur due to sprouting, drying and rotting [6].

Bulb rots are a common cause of onion loss during storage. They are caused by microorganisms particularly fungi. The black mould disease caused by Aspergillus niger is a limiting factor in onion production worldwide [6]. Aspergillus niger has been reported to survive between onion crops as a soil saprophyte in or on bulbs in field or storage and is ubiquitous in nature. The fungus invades bulbs of onions in field or storage whenever they find injured tissues by producing various enzymes or toxins [7]. Association of Aspergillus niger with onion seeds produced in hot climates and their transmission from soil and naturally-contaminated seeds to onion seedlings cause $30-80 \%$ loss or spoilage of onion bulbs.

The deterioration of raw onions may result from physical factors, actions of their own enzymes, microorganisms or a combination of these factors. Mechanical damage resulting from actions of animals, birds or insects or from mishandling may predispose towards increased enzymatic action or entrance and growth of microorganisms. Previous damage by plant pathogens may make the part of the crop used as food unfit for consumption or may open the path for the growth of saprophytes and spoilage by them. Contact with spoilage onions may bring about the transfer of organisms causing spoilage and increasing their wastage. Unfavourable 
environmental conditions during harvest, transit, storage and marketing may favour spoilage.

Fungal infections can also increase the chances of contamination by mycotoxins which are potential hazards to human and animal health. These toxins have been reported to cause neurological disorders, cancer of the liver and lung. Storage rots lead to a reduction in the quality and quantity of onions which affect the market value. Another important consequence is the contamination of the affected fruits by mycotoxins [8].

Many molds capable of producing mycotoxins are also frequent contaminants of onion bulbs. Members of the genera Aspergillus and Fusarium are involved in mycotoxins production. Apart from toxins production, the presence of fungi on onion bulbs eventually leads to disease development in the field when the infected bulbs are planted in the preceding cropping season, therefore in this work, the fungi associated with the deterioration of post-harvest onion bulbs sold in some Awka Markets, Nigeria were isolated, characterized and identified. The result of the study will add to the existing literature and also educate the public on the dangers inherent in the use of fungi-contaminated onion bulbs both for consumption and agriculture.

\section{Materials and Methods}

\subsection{Samples Collection and Processing}

Thirty samples of onions with signs of spoilage were bought from Umuike, Amaikwo, Amaudo, Okpuno and Permanent Site Markets Awka, Nigeria. Thirty healthy onion bulbs were later bought from the same markets for the pathogenicity test (fifteen as test and fifteen as control samples). The samples were each transported in a sterile polythene bag to the microbiology laboratory for fungal isolation.

The isolation was carried out under aseptic conditions. All the glass wares used were properly washed, dried and sterilized in an oven at $160^{\circ} \mathrm{C}$ for one hour. The entire working surfaces were also disinfected with ethanol to reduce contaminants. Each of the thirty onion bulbs with the signs of spoilage were cut with a sterile knife and crushed. One milliliter of the crushed bulb was thereafter serially-diluted using sterile distilled water.

\subsection{Fungal Isolation}

The spread plate technique was employed. Aliquots $(\mathrm{lml})$ of the serially-diluted sample $\left(10^{3}\right)$ was spread on the surface of potato dextrose agar (PDA) contained in a sterile petri dish. The petri dish also had two percent Chloramphenicol added to inhibit bacterial growth. Incubation was carried out in an inverted position at $28^{\circ} \mathrm{C}$ for five days. The fungal colonies that developed were purified by repeated subculturing on sterile PDA and later stored on PDA slants for characterization and identification.

\subsection{Characterization and Identification of the Fungal Isolates}

The molds were characterized and identified using the slide culture technique and microscopic examination while the yeasts were characterized and identified using the Chlamydospores formation, Germ tube, Sugar assimilation, Motility, Gram stain and Urease tests. The identity of each fungus was confirmed using a mycological atlas.

\subsubsection{Slide Culture Technique}

A small portion of the aerial mycelia was inoculated on a slide containing prepared potato dextrose agar using a sterile inoculating needle. The slide was incubated at room temperature for twenty-four hours after which it was viewed under the microscope.

\subsubsection{Microscopic Examination}

Microscopic examination was carried out using the lactophenol cotton blue solution. A drop of the solution was introduced on a clean grease-free slide and a fragment of the test fungus was removed and introduced into the stain with the aid of a sterile straight wire loop. The fungus was spread properly on the slide which was thereafter covered with a coverslip, avoiding bubbles. The excess stain was removed by blotting with Whatman No. 1 filter paper and the slide was then viewed under the microscope.

\subsubsection{Chlamydospore Formation Test}

The method of Menza et al [9] was employed. The isolates were inoculated on corn meal agar containing tween 80 and incubated at $25^{\circ} \mathrm{C}$ for seventy-two hours. The isolates were thereafter introduced on a slide and stained with lactophenol cotton blue solution. The slide was then viewed under the microscope for Chlamydospore formation.

\subsubsection{Germ Tube Test}

The test was performed using the procedure of Menza et al [9]. A colony of the test yeast cell was inoculated in human serum and incubated at $37^{\circ} \mathrm{C}$ for three hours. A drop of the incubated serum was placed on a microscope slide and covered with a coverslip and examined under the microscope for the presence of germ tube.

\subsubsection{Sugar Assimilation Test}

The test was carried out using the procedure of Menza et al [9]. Carbohydrate impregnated filter paper disc were placed on sterile carbohydrate -free yeast nitrogen base agar contained in petri dishes and incubated at $30^{\circ} \mathrm{C}$ for eighteen hours. The growth around the carbohydrate-free filter paper discs was thereafter observed. Growth in the medium indicated the ability of the isolate to assimilate a sugar. The sugars used were glucose, lactose, sucrose, galactose and raffinose.

\subsubsection{Motility Test}

Hanging drop slides were used to carry out the test. Vaseline was spread with a sterile toothpick on the corners of 
a clean coverslip. A drop of the yeast suspension was aseptically placed on the centre of the coverslip with a sterile inoculating loop. The depression slide was lowered onto the coverslip so that the drop protruded into the centre of the concavity of the slide. The hanging drop slide was turned over and placed on the stage of the microscope so that the drop was on the light hole. The drop was thereafter viewed under the microscope.

\subsubsection{Gram Stain}

A smear of the yeast cell was made on a slide and stained using the gram stain procedure. The slide was thereafter examined under the microscope for the presence of gram positive yeast cells.

\subsection{Pathogenicity Test of the Fungal Isolates}

The methods of Baiyewu et al [10] and Chukwuka et al [11] were used for the test. Fifteen healthy onion bulbs were properly washed with tap water, rinsed with distilled water and their surfaces disinfected with ethanol. A sterile cork borer was used to make holes in each onion bulb and each of the isolated fungi was thereafter inoculated into the onion bulbs after which the cores of the onion bulbs were replaced. Petroleum jelly was used to seal the holes to prevent contamination. Fifteen onion bulbs wounded with the cork borer but were not inoculated with the fungi were used as controls.

The inoculated onion bulbs and the controls were placed in sterile polythene bags (one bulb per bag). Each of the onions was moistened with wet balls of absorbent cotton wool to create a humid environment and incubated at $28^{\circ} \mathrm{C}$ for five days and observed for signs of spoilage. The fungi were re-isolated from the inoculated onion bulbs and compared with the original isolates. The decay rate of the onion bulbs was also determined after two weeks of the inoculation by measuring their diameter of rot.

\section{Results}

The average fungal counts of the spoilt onion bulbs are presented in Table 1. The counts were $1.5 \times 10^{3} \mathrm{cfu} / \mathrm{ml}, 1.6 \mathrm{x}$ $10^{3} \mathrm{cfu} / \mathrm{ml}, 2.0 \times 10^{3} \mathrm{cfu} / \mathrm{ml}, 1.2 \times 10^{3} \mathrm{cfu} / \mathrm{ml}$ and $1.8 \times 10^{3}$ $\mathrm{cfu} / \mathrm{ml}$ for the onion bulbs from Umuike, Amaikwo, Amaudo, Okpuno and Permanent Site Markets.

Table 1. Average fungal counts of the spoilt onion bulbs

\begin{tabular}{|c|c|}
\hline Market & Average fungal count $\mathbf{( c f u / m l )}$ \\
\hline Umuike & $1.5 \times 10^{3}$ \\
\hline Amaikwo & $1.6 \times 10^{3}$ \\
\hline Amaudo & $2.0 \times 10^{3}$ \\
\hline Okpuno & $1.8 \times 10^{3}$ \\
\hline Permanent Site & $1.2 \times 10^{3}$ \\
\hline
\end{tabular}

The fungal species isolated from the spoilt onion bulbs are shown in Table 2. They were identified as Penicillium digitatum, Fusarium oxysporum, Rhizopus stolonifer, Alternaria alternata, Aspergillus niger and Saccharomyces cerevisiae. Penicillium digitatum was isolated from the samples from Amaikwo market only, Fusarium oxysporum from the samples from Umuike, Amaudo and Okpuno markets, Rhizopus stolonifer from the samples from Umuike and Okpuno markets, Alternaria alternata and Aspergillus niger from the samples from all but Umuike markets while Saccharomyces cerevisiae were isolated from the samples from Amaudo market only.

Table 2. Fungal species isolated from the spoilt onion bulbs

\begin{tabular}{|c|c|}
\hline Market & Fungal species \\
\hline Umuike & $\begin{array}{c}\text { Fusarium oxysporum and Rhizopus } \\
\text { stolonifer }\end{array}$ \\
\hline Amaikwo & $\begin{array}{c}\text { Aspergillus niger, Alternaria alternata and } \\
\text { Penicillium digitatum }\end{array}$ \\
\hline Amaudo & $\begin{array}{c}\text { Aspergillus niger, Fusarium oxysporum, } \\
\text { Saccharomyces cerevisiae and Alternaria } \\
\text { alternata }\end{array}$ \\
\hline Okpuno & $\begin{array}{c}\text { Aspergillus niger, Fusarium oxysporum, } \\
\text { Alternaria alternata and Rhizopus stolonifer }\end{array}$ \\
\hline Permanent Site & Alternaria alternata and Aspergillus niger \\
\hline
\end{tabular}

The distribution of the fungi in relation to the markets is presented in Table 3. The percentage distribution was $14.3 \%$, $20.0 \%, 34.2 \%, 22.9 \%$ and $8.6 \%$ for the samples from Umuike, Amaikwo, Amaudo, Okpuno and Permanent Site Markets respectively.

Table 3. Distribution of the fungi in relation to the markets.

\begin{tabular}{|c|c|c|c|c|c|c|c|}
\hline Market & $\begin{array}{c}\text { Penicillum } \\
\text { digitatum } \\
\text { (n) }\end{array}$ & $\begin{array}{c}\text { Fusarium } \\
\text { Oxysporum } \\
\text { (n) }\end{array}$ & $\begin{array}{c}\text { Rhizopus } \\
\text { stolonifer } \\
\text { (n) }\end{array}$ & $\begin{array}{c}\text { Alternaria } \\
\text { alternate } \\
\text { (n) }\end{array}$ & $\begin{array}{c}\text { Aspergillus } \\
\text { niger } \\
\text { (n) }\end{array}$ & $\begin{array}{c}\text { Sacchromyces } \\
\text { cerevisiae } \\
\text { (n) }\end{array}$ & Distribution \% \\
\hline Umuike & 0 & 2 & 3 & 0 & 0 & 0 & 14.3 \\
\hline Amaikwo & 4 & 0 & 0 & 1 & 2 & 0 & 20.0 \\
\hline Amaudo & 0 & 2 & 0 & 3 & 5 & 3 & 0 \\
\hline Okpuno & 0 & 2 & 1 & 2 & 2 & 0 & 22.9 \\
\hline Permanent Site & 0 & 0 & 0 & 1 & 2 & 0 \\
\hline
\end{tabular}

$\mathrm{n}=$ Number of isolates 
The percentage distribution of the fungi in the spoilt onion bulbs is shown in Table 4. The percentage distribution was $11.43 \%, 17.14 \%, 11.43 \%, 20.00 \%, 34.29 \%$ and $5.71 \%$ for Penicillium digitatum, Fusarium oxysporum, Rhizopus stolonifer, Alternaria alternata, Aspergillus niger and Saccaromyces cerevisiae respectively.

Table 4. Percentage distribution of the fungi from the spoilt onion bulbs

\begin{tabular}{|c|c|c|}
\hline Fungi & No. of isolates & \% Distribution \\
\hline Penicillium digitatum & 4 & 11.43 \\
\hline Fusarium oxysporum & 6 & 17.14 \\
\hline Rhizopus stolonifer & 4 & 11.43 \\
\hline Alternaria alternata & 7 & 20.00 \\
\hline Aspergillus niger & 12 & 34.29 \\
\hline Saccaromyces cerevisiae & 2 & 5.71 \\
\hline
\end{tabular}

The decay rate of the fungi in the healthy onion bulbs is presented in Table 5 . The rot diameters were $28 \mathrm{~mm}, 33 \mathrm{~mm}$, $26 \mathrm{~mm}, 36 \mathrm{~mm}, 40 \mathrm{~mm}$, and $16 \mathrm{~mm}$ for Penicillium digitatum, Fusarium oxysporum, Rhizopus stolonifer, Alternaria alternata, Aspergillus niger and Saccaromyces cerevisiae respectively.

Table 5. Decay rate of the fungi in the healthy onion bulbs

\begin{tabular}{|c|c|}
\hline Fungi & Rot Diameter $(\mathrm{mm})$ \\
\hline Penicillium digitatum & 28 \\
\hline Fusarium oxysporum & 33 \\
\hline Rhizopus stolonifer & 26 \\
\hline Alternaria alternata & 36 \\
\hline Aspergillus niger & 40 \\
\hline Saccaromyces cerevisiae & 16 \\
\hline
\end{tabular}

\section{Discussion}

Studies on the fungi associated with the spoilage of onion bulbs sold in some markets in Awka, Nigeria showed that the onion bulbs contained a teeming population of fungi. The average fungal counts ranged between $1.2 \times 10^{3} \mathrm{cfu} / \mathrm{ml}$ and $2.0 \times 10^{3} \mathrm{cfu} / \mathrm{ml}$. The samples from Amaudo market had the highest count of $2.0 \times 10^{3} \mathrm{cfu} / \mathrm{ml}$ while those from the permanent site market had the lowest count of $1.2 \times 10^{3}$ $\mathrm{cfu} / \mathrm{ml}$ (Table 1).

The fungi isolated from the spoilt onion bulbs were identified as Penicillium digitatum, Fusarium oxysporum, Rhizopus stolonifer, Alternaria alternata, Aspergillus niger and Saccharomyces cerevisiae (Table 2).

Shehu and Muhammad [12] also isolated Aspergillus niger, Rhizopus stolonifer and Fusarium oxysporum from the rotten onion bulbs sold at five different markets in Sokoto, Nigeria. Dimkpa and Onuegbu [13] also implicated fungi as contaminants of many agricultural commodities including onions. Narayana et al [14] also reported Aspergillus niger as the causative agent of black mold rot of onions.

The percentage distribution of the fungi in the spoilt onion bulbs in relation to the markets showed the highest percentage distribution of $34.2 \%$ for the samples from Amaudo market and the lowest percentage distribution of $8.6 \%$ for the samples from temporary site market (Table 3 ).

Aspergilus niger had the highest percentage distribution of $34.28 \%$ in the onion bulbs studied while saccharomyces cerevisiae had the lowest percentage distribution of $5.71 \%$ (Table 4). This result agreed with Shehu and Muhammad [12] who reported the highest frequency of occurrence of $30.0 \%$ for Aspergillus niger in the onion bulbs they studied. Chukwuka et al [11] however reported Rhizopus sp as the most predominant fungus in the onion bulbs they studied.

The pathogenicity test result showed that the fungi inoculated into the healthy onion bulbs had the same characteristics as the fungal species re-isolated from the same healthy bulbs showing that the fungal isolates were responsible for the spoilage of the onion bulbs. Aspergillus niger caused the highest decay with a rot diameter of $40 \mathrm{~mm}$ (Table 5).This result is however at variance with that of Shehu and Muhammad [12] who reported the lowest rot diameter of $12 \mathrm{~mm}$ for Aspergillus niger.

The presence of these fungi in the onion bulbs is attributable to the environmental conditions, state of handling and processing, state of storage facility of the onions, the fungal load of the handlers and the quality of the onion bulbs. These fungi have been known to cause diseases of humans and animals. They may come from the air, water, soil and even the handlers. They are the sources of highly potent mycotoxins which are hazardous to health. The presence of these fungi in significant numbers in onion bulbs is therefore a public health risk.

Fungal spoilage of onions also has a negative economic effect on the economy of the onion bulbs farmers in particular and the economy of the country in general. The control of the fungal spoilage of onion bulbs is therefore inevitable. Proper storage conditions, careful harvesting, protection of the bulbs from sunburn, provision of adequate ventilation and regular examination during storage will minimize the entry and proliferation of these organisms in the onion bulbs, thereby reducing the incidence of diseases they cause and also improve the economy by reducing wastes resulting from spoilages.

\section{Conclusions}

The high occurrence of fungi in the spoilt onion bulbs is a public health risk. Appropriate control measures must be employed during the harvesting, processing, transportation, and handling of the fruits. Good storage facilities should also be put in place to protect the onion bulbs from attacks by these fungi, thereby minimizing wastes due to deterioration and unacceptability. The consumption of raw onions without prior heat treatment should be discouraged. 


\section{REFERENCES}

[1] L. Velez, R.P. Rodrignez, J. Cabera. Fungi associated with onion (Allium cepa L.) field in Southern Puerto Rico. Journal of Agriculture of the University of Puerto Rico, Vol. 88, No. 1, 55-72, 2004. http://www.crl.edu.

[2] N. Benkeblia. Antimicrobial activity of essential oil extracts of various onions (Allium cepa) and garlic (Allium sativum). Food Science and Technology, Vol.37, No.2, 263-268, 2004. DOI:10.1016/j.iwt.2003.09.001

[3] H. Ole, L. Torben, L.P. Christensen, K. Ulla, H. Nazmul, H. T. Shakuntala. Contents of Iron, Calcium, Zinc and B-carotene in commonly consumed vegetables in Bangladesh. Journal of Food composition and analysis, Vol. 17, No.5, 587-595, 2004. http://www.sciencedirect.com/science/journal/08891575/17/ 5.

[4] L.O. Adebajo, S.A. Diyaolu. Mycology and spoilage of retail cashew nuts. African Journal of Biotechnology, Vol, 2, 369-373, 2003. DOI: 10.5897/AJB 2003.000-1076

[5] R.E. Uzeh, F.A. Alade, M. Bankole. The microbial quality of pre-packed mixed vegetable salad in some retail outlets of Lagos, Nigeria. African Journal of Food science, Vol. 3, No.9, 270-272, 2009.

http://www.academicjournals.org/journal/AJFS/article-abstra ct/B3368A920494

[6] J.L. Tyson, R.A. Fullerton. Effect of soil borne-inoculum on incidence of onion black mould (Aspergillus niger). New Zealand Plant Protection, Vol. 57, 138-141, 2004. http://www.researchgate.net/publication/271078061

[7] K.Raju, M.K. Naik. Effect of Pre-harvest spray of fungicides and botanicals on storage diseases on onion. Indian Phyto-Pathology. Vol.59, No.2, 133-141, 2006. http://www.researchgate.net/publication/267216383

[8] S. Muhammed, K. Shehu, N.A. Amusa. Survey of the market diseases and aflatoxin contamination of fruits and vegetables in Sokoto, North western, Nigeria. Nutrition and Food science, Vol. 34, No.2, 72-76, 2004. DOI:

http://dx.doi.org/10.1108/00346650410529032.

[9] N. Menza, W. Wanyoike, W.M. Muturi. Prevalence of vaginal candidiasis and determination of the occurrence of Candida species in pregnant women attending the ante-natal clinic of Thika district hospital, Kenya. Open Journal of Medical Microbiology. Vol.3, No.4, 1-9, 2013 DOI: 10.4236/ojmm.2013.34040.

[10] R.A. Baiyewu, N.A. Amusa, O.A. Ayoola, O.O. Babalola. Survey of the postharvest diseases and aflatoxin contamination of marketed pawpaw fruit (Carica papaya L.) in South Western Nigeria. African Journal of Agricultural Research, Vol. 2, No.4, 178-181, 2007.

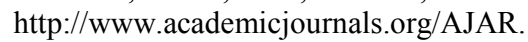

[11] K.S. Chukwuka, I.O. Okonko, A.A. Adekunle. Microbial Ecology of organisms causing pawpaw (Carica papaya L.) fruit decay in Oyo State, Nigeria. American-Eurasian Journal of Toxicological Sciences, Vol.2, No.1, 43-50, 2010. http://www.idosi.org/aejts/aejts2(1)10.htm.

[12] K. Shehu, S. Muhammad. Fungi associated with storage rots of onion bulbs in Sokoto, Nigeria. International Journal of Modern Botany, Vol.1, No. 1, 1-3, 2011. doi: 10.5923/j.ijmb.20110101.01

[13] S.O.N. Dimkpa, B.A. Onuegbu. Mycoflora of copra and effect of brining on some properties of copra in Nigeria. Agriculture and Biology Journal of North America, Vol.1, No.3, 391-394, 2010.

Scihub.org/ABJNA/PDF/2010/3/1-3-391-394.

[14] K.J.P. Narayana, M. Srikanth, M. Vijayalakshmi, N. Lakshmi. Toxic Spectrum of Aspergillus niger causing black mold rot of onions. Research Journal of Microbiology, Vol.2, 881-884, 2007. DOI: $10.3923 / j m .2007 .881 .884$. 